\title{
The impact of bioinsecticide overdoses of Beauveria bassiana on species diversity and abundance of not targeted arthropods in South Sumatra (Indonesia) freshwater swamp paddy
}

\author{
KHOIRUL IKHSANUDIN HANIF ${ }^{1}$, SITI HERLINDA ${ }^{1,2,3,5, \vartheta}$, CHANDRA IRSAN ${ }^{1,2,3,5}$, YULIA PUJIASTUTI ${ }^{1,2,3,5}$, \\ GHANNI PRABAWATI ${ }^{1}$, HASBI $^{3,4,5}$, TILI KARENINA ${ }^{5}$ \\ ${ }^{1}$ Program of Crop Sciences, Faculty of Agriculture, Universitas Sriwijaya. Jl. Padang Selasa No. 524, Palembang 30139, South Sumatra, Indonesia \\ ${ }^{2}$ Department of Plant Pests and Diseases, Faculty of Agriculture, Universitas Sriwijaya, Indralaya, Ogan Ilir 30662, South Sumatra, Indonesia. \\ Tel.: +62-711-580663, Fax.: +62-711-580276, "email: sitiherlinda@unsri.ac.id \\ ${ }^{3}$ Research Center for Sub-optimal Lands (PUR-PLSO), Universitas Sriwijaya. Jl. Padang Selasa No.524, Palembang 30139, South Sumatra, Indonesia \\ ${ }^{4}$ Department of Agricultural Engineering, Faculty of Agriculture, Universitas Sriwijaya. Jl. Raya Palembang-Prabumulih Km 32, Indralaya, Ogan Ilir \\ 30662, South Sumatra, Indonesia \\ ${ }^{5}$ Postgraduate Program of Agriculture Sciences, Faculty of Agriculture, Universitas Sriwijaya. Jl. Padang Selasa No.524, Palembang 30139, South \\ Sumatra, Indonesia
}

Manuscript received: 20 January 2020. Revision accepted: 22 April 2020

\begin{abstract}
Hanif KI, Herlinda S, Irsan C, Pujiastuti Y, Prabawati G, Hasbi, Karenina T. 2020. The impact of bioinsecticide overdoses of Beauveria bassiana on species diversity and abundance of not targeted arthropods in South Sumatra (Indonesia) freshwater swamp paddy. Biodiversitas 21: 2124-2136. Bioinsecticides have been shown to reduce insect pest populations, but it is necessary to monitor the effect of bioinsecticide overdoses on non-target arthropods because they are abundant in rice fields. This study aimed to analyze the impact of bioinsecticide overdoses of B. bassiana on species diversity and abundance of non-target arthropods. Bioinsecticides derived from Beauveria bassiana were sprayed on the paddy every two weeks until the ripening stage, at a dose of $1,2,3,4$ L.ha ${ }^{-1}$, control (without insecticide), and abamectin as prescribed. The abundance of spiders and predatory arthropods did not decrease when bioinsecticides were applied but the abundance of spiders, especially Lycosidae and Salticidae dropped significantly when abamectin was applied. The abundance of the parasitoid decreased significantly when abamectin was applied, but the abundance of parasitoids applied by bioinsecticide was not significantly different from those of control. The abundance of insect pests started to decrease when

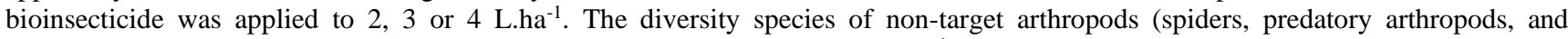
parasitoids) tended to decrease when it was applied bioinsecticides 3 and 4 L.ha ${ }^{-1}$ or abamectin, but their abundance remained high and no species dominance was found. For this reason, the correct dosage for suppressing insect pests abundance by not decreasing the abundance and diversity of non-target species is 2 L.ha ${ }^{-1}$ and applied when herbivore abundance is high.
\end{abstract}

Keywords: Abamectin, insect pests, parasitoids, predatory arthropods, spiders

\section{INTRODUCTION}

Freshwater swamps are wetland ecosystems flooded with river water or rain throughout the year. The duration of the puddle in freshwater swamps depends on the typology of the land, namely deep, rather deep, and shallow. The swamp typology is generally inundated for most of the year (October to July), rather deep swamps are inundated from November to June, and shallow swamps are inundated from November to April. When lands are inundated, smallholders usually underutilize their lands. Herlinda et al. (2018) stated that the smallholders started to grow paddy in April or no later than July. They generally grew once a year (Herlinda et al. 2018; Lakitan et al. 2019). Therefore, land productivity and cropping intensity were low (Lakitan et al. 2019).

Increasing land productivity needs to be conducted carefully and sustainably because freshwater swamps are fragile ecosystems (Lakitan et al. 2019; Siaga et al. 2019). The efforts of increasing land productivity were started by business farmers by regulating water management and damming/canalization of land covering an area of between 250 and 500 ha so that they can increase the intensity of rice planting from once a year to two or three times a year. However, according to Herlinda et al. (2019a), the increase of planting intensity caused business farmers to start applying intensive and scheduled synthetic insecticides. In order to maintain sustainable agriculture, it is necessary to introduce business farmers and smallholders the bioinsecticide which is relatively environmentally friendly and safe for rice products.

Bioinsecticides made from entomopathogenic fungi, such as Beauveria bassiana, have been proven to be effective in controlling various species of insect pests. $B$. bassiana can kill paddy insects such as brown plant hoppers (BPH) (Li et al. 2014; Sumikarsih et al. 2019), Spodoptera litura (Ayudya et al. 2019). The research results in the laboratory proved that $B$. bassiana did not harm the natural enemies of BPH (non-target arthropods) (Firouzbakht et al. 2015; Gholamzadeh-Chitgar et al. 2017). However, caution is needed in applying the bioinsecticide because the non-target arthropod species is 
very abundant, rich, and diverse in the paddy ecosystem of freshwater swamps in South Sumatra, such as spiders (Herlinda et al. 2018), predatory insects, parasitoids, and neutral insects (Herlinda et al. 2019b; Karenina et al. 2019) if an overdose can affect the abundance and diversity of non-target arthropods. The neutral insects, which were insects that did not act as herbivores or natural enemies of herbivores. This study aimed to analyze the impact of bioinsecticide overdoses of B. bassiana on species diversity and abundance of non-target arthropods.

\section{MATERIALS AND METHODS}

This research has been carried out in the village of Pelabuhan Dalam, Pemulutan Subdistrict, Ogan Ilir District, South Sumatra, which is a center of freshwater swampy rice. The research site is surrounded by a paddy monoculture of \pm 800 ha, which is generally planted from April or May to September or November each year. The field experiment was carried out from April to September 2018, and then the arthropods samples were taken and identified in the laboratory from October 2018 to March 2019. Paddy cultivation methods followed the pattern carried out by the smallholders but this study used certified Mekongga varieties with purple label and planting system of "jajar legowo" 2:1 with a spacing of $50 \times 25 \times 12.5 \mathrm{~cm}^{3}$. The area of each treatment plot was $38 \times 20 \mathrm{~m}^{2}$ which was repeated 3 times (total $2280 \mathrm{~m}^{2}$ ) where the distance between plots was $10 \mathrm{~m}$.

\section{Preparation of land and paddy seedlings}

Preparation of land and rice planting began with tillage, seeding, planting, and maintaining of paddy. Land management was conducted using mini plows and mashed using hoes. After the soil was processed, manure with a dose of 1 ton.ha ${ }^{-1}$ was mixed into the treated soil. The paddy seeds were first soaked with water for $24 \mathrm{~h}$, and then the seeds were planted using a "samir" system. The varieties used were certified with purple labels and a dose of $50 \mathrm{~kg} \cdot \mathrm{ha}^{-1}$. After the seedlings were 5 days old, the seeds were moved into shallow rice fields and waited until they reached 14 days old. Then, the 14-day-old seedlings were transplanted in the fields.

\section{Paddy planting and maintenance}

The paddy planted with a 2:1 "jajar legowo" system with the plant spacing of $50 \times 25 \times 12.5 \mathrm{~cm}^{3}$. The number of seedlings planted is 2-3 stems per hole. The maintenance was carried out by mechanical weeding using sickles. The water management used pumping. The fertilization used liquid compost extract at a dose of $1 \mathrm{~L}^{\mathrm{h}} \mathrm{ha}^{-1}$ per two weeks from the age of 2 weeks to milky stage. The making of liquid compost extraction used the method of Suwandi et al. (2012) was carried out by means of $2 \mathrm{~L}$ of microbial culture of remodel mixed with $200 \mathrm{~L}$ of water, $10 \mathrm{~kg}$ of manure, $2 \mathrm{~kg}$ of NPK fertilizer, and $2 \mathrm{~kg}$ of phosphate fertilizer and fermented for 1-2 weeks. The liquid compost extract containing Trichoderma virens was used for plant nutrition.

\section{The producing of bioinsecticides and their applications}

Bioinsecticides applied in this study were made from conidia of $B$. bassiana with a carrier material of compost shrimp shell and the making of the compost extract used the method of Suwandi et al. (2012). As a bioinsecticide stabilizer, $30 \%$ sucrose (w/v) volume of bioinsecticide and $1 \%(\mathrm{v} / \mathrm{v})$ vegetable oil were added. Conidia B. bassiana was propagated in SDA media using the method of Safitri et al. (2018). After that, it was cultured in liquid media (SDB) incubated and shaken on a shaker for 7 days. This liquid culture was added to liquid compost extract as a carrier and stabilizer of sucrose and vegetable oil. This bioinsecticide was first stored for 1 month before being applied in paddy and the bioinsecticide conidia density was at least $1 \times 10^{9}$ conidia. $\mathrm{mL}^{-1}$.

Bioinsecticide was applied in the afternoon around 5 p.m. to prevent the death of conidia due to the ultraviolet light during the day. The doses used were 1, 2, 3, 4 L.ha-1, control (without treatment $=0$ L.ha ${ }^{-1}$ ), a commercial insecticide (abamectin). The spraying began when the paddy reached $14,28,42,56,70,84$ days old after the transplanting (DAT). Abamectin is a biological insecticide with broad-spectrum activity (Ananiev et al. 2002) and this product was chosen in this research due to farmers in Indonesia often using it to control a brown planthopper (BPH), Nilaparvata lugens.

\section{Sampling arthropods in paddy}

The sampling of arthropods in paddy was carried out using insect nets (sweep nets) using the method of Weilhoefer et al. (2017). The arthropods sampling was conducted $1 \times 24 \mathrm{~h}$ after spraying the bioinsecticide in the morning around 6.00-7.00 am. The sampling was carried out in the morning when the arthropods were not very active so that the data obtained were more valid. The arthropods were taken as many as 5 nets whose scattered positions were taken in the plot and repeated three times. The study design used a randomized group design. The arthropod sampling was carried out when the paddy reached 15, 29, 43, 57, 71, 85 DAT. The arthropods samples were then taken to the laboratory for sorting, cleaning, and then put in vial bottles containing $70 \%$ alcohol. The arthropods were identified by referring to the source textbooks of Kalshoven (1981), McAlpine et al. (1987), and Barrion and Litsinger (1995)

\section{Data analysis}

The data on the number of individuals of each arthropod species from each treatment were used to analyze species abundance and diversity. The abundance of arthropods during one paddy planting season was compared between the treatments using ANOVA assisted by the Software Program of SAS University Edition 2.7 9.4 M5. The species diversity was analyzed using the Shannon-Wiener ( $\left.\mathrm{H}^{\prime}\right)$ index, dominance (D), and Evenness (E) using the Magurran handbook (Magurran 1988). The grouping data were based on guilds, namely predators (spiders and predatory insects), parasitoids, herbivores, and neutral insects displayed in graphical forms. The non-target guilds were focused on predators (spiders and predatory insects) and parasitoids. 


\section{RESULTS AND DISCUSSION}

\section{The arthropods species in paddy applied with bioinsecticide}

Predatory species found in this study were grouped into spiders and predatory insects. During one paddy planting season, all spider species were found as many as 31 species (Table 1). The dominant spider species found include Pardosa birmanica, Pardosa patapatensis, Pardosa pseudoannulata, Pardosa pullata, Pardosa sumatrana. The number of species found in each bioinsecticide dose showed a tendency, the higher the dose the less number of species found in the paddy. The number of spider species dropped dramatically in plots at 4 L.ha ${ }^{-1}$ and abamectin. In addition to spiders, predatory insects were found during one paddy planting season as many as 20 species (Table 2). The dominant predatory insects which were found were Micrapis inops, Verania lineata, Ophionea nigrofasciata, and Paederus fuscipes. The number of species found decreases with the increasing doses of bioinsecticide and the application of abamectin. The number of spider species dropped dramatically in plots at 3 and 4 L.ha $^{-1}$ and abamectin.

Table 1. Spider abundance inhabiting on the paddy applied with bioinsecticide of Beauveria bassiana, control without treatment $(0$ L.ha ${ }^{-1}$ ), and abamectin

\begin{tabular}{|c|c|c|c|c|c|c|c|c|c|}
\hline \multirow{3}{*}{ Family/species } & \multicolumn{6}{|c|}{ Mean of abundance (individuals/5 nets) } & \multirow{3}{*}{$\begin{array}{c}\text { ANOVA } \\
\text { F-value }\end{array}$} & \multirow{3}{*}{ P value } & \multirow{3}{*}{$\begin{array}{l}\text { Tukey's } \\
\text { HSD test }\end{array}$} \\
\hline & \multicolumn{5}{|c|}{ Beauveria bassiana (L.ha-1) } & \multirow{2}{*}{ Abamectin } & & & \\
\hline & $\mathbf{0}$ & 1 & 2 & 3 & 4 & & & & \\
\hline Araneidae & $0.00^{\mathrm{a}}$ & $0.50^{\mathrm{b}}$ & $0.00^{\mathrm{a}}$ & $0.00^{\mathrm{a}}$ & $0.00^{\mathrm{a}}$ & $0.00^{\mathrm{a}}$ & 5.00 & 0.00 & 0.17 \\
\hline Araneus inustus & 0.00 & 0.33 & 0.00 & 0.00 & 0.00 & 0.00 & 2.50 & 0.06 & - \\
\hline Araneus sp. A & 0.00 & 0.17 & 0.00 & 0.00 & 0.00 & 0.00 & 1.00 & 0.43 & - \\
\hline Linyphiidae & 0.17 & 0.17 & 0.17 & 0.17 & 0.33 & 0.00 & 0.41 & 0.83 & \\
\hline Atypena adelinae & 0.00 & 0.17 & 0.00 & 0.00 & 0.00 & 0.00 & 1.00 & 0.43 & - \\
\hline Atypena formosana & 0.00 & 0.00 & 0.00 & 0.00 & 0.33 & 0.00 & 2.50 & 0.06 & - \\
\hline Bathyphantes tagalogensis & 0.17 & 0.00 & 0.00 & 0.00 & 0.00 & 0.00 & 1.00 & 0.43 & - \\
\hline Erigone bifurca & 0.00 & 0.00 & 0.17 & 0.00 & 0.00 & 0.00 & 1.00 & 0.43 & - \\
\hline Wendilgarda liliwensis & 0.00 & 0.00 & 0.00 & 0.17 & 0.00 & 0.00 & 1.00 & 0.43 & - \\
\hline Lycosidae & $2.83^{\mathrm{b}}$ & $2.33^{\mathrm{ab}}$ & $1.50^{\mathrm{ab}}$ & $2.50^{\mathrm{b}}$ & $2.50^{\mathrm{b}}$ & $0.83^{\mathrm{a}}$ & 3.73 & 0.01 & 0.53 \\
\hline Pardosa apostoli & 0.00 & 0.17 & 0.00 & 0.17 & 0.00 & 0.17 & 0.65 & 0.66 & \\
\hline Pardosa birmanica & 0.67 & 0.50 & 0.33 & 0.67 & 0.83 & 0.00 & 1.42 & 0.25 & - \\
\hline Pardosa patapatensis & 0.50 & 0.33 & 0.50 & 0.33 & 0.00 & 0.00 & 1.38 & 0.26 & - \\
\hline Pardosa pseudoannulata & 1.00 & 0.83 & 0.50 & 0.33 & 1.00 & 0.50 & 1.11 & 0.37 & - \\
\hline Pardosa pullata & 0.00 & 0.00 & 0.00 & 0.00 & 0.17 & 0.00 & 1.00 & 0.43 & - \\
\hline Pardosa sumatrana & 0.67 & 0.50 & 0.17 & 1.00 & 0.50 & 0.17 & 1.14 & 0.36 & - \\
\hline Oxyopidae & 2.00 & 0.83 & 1.67 & 2.33 & 0.83 & 0.67 & 2.80 & 0.04 & - \\
\hline Oxyopes javanus & 0.50 & 0.17 & 0.83 & 0.67 & 0.67 & 0.33 & 1.41 & 0.26 & - \\
\hline Oxyopes liniatipes & 0.17 & 0.00 & 0.17 & 0.50 & 0.00 & 0.17 & 1.50 & 0.22 & - \\
\hline Oxyopes matiensis & 0.17 & 0.17 & 0.17 & 0.00 & 0.00 & 0.00 & 0.55 & 0.73 & - \\
\hline Oxyopes pingasus & 1.17 & 0.50 & 0.50 & 1.17 & 0.17 & 0.17 & 3.42 & 0.02 & - \\
\hline Salticidae & $0.83^{\mathrm{ab}}$ & $0.83^{\mathrm{b}}$ & $1.00^{\mathrm{ab}}$ & $0.17^{\mathrm{a}}$ & $0.67^{\mathrm{ab}}$ & $0.33^{\mathrm{a}}$ & 3.81 & 0.01 & 0.41 \\
\hline Camaricus formosus & 0.17 & 0.00 & 0.00 & 0.00 & 0.00 & 0.00 & 1.00 & 0.43 & - \\
\hline Harmochirus braciatus & 0.00 & 0.17 & 0.00 & 0.00 & 0.00 & 0.00 & 1.00 & 0.43 & - \\
\hline Rhene hinlalakea & 0.67 & 0.50 & 0.50 & 0.17 & 0.33 & 0.17 & 0.59 & 0.70 & - \\
\hline Rhene sp. A & 0.00 & 0.17 & 0.50 & 0.00 & 0.33 & 0.17 & 1.41 & 0.25 & - \\
\hline Tetragnathidae & 5.83 & 5.50 & 5.33 & 4.33 & 5.17 & 3.00 & 3.07 & 0.03 & - \\
\hline Tetragnatha desaguni & 0.00 & 0.33 & 0.33 & 0.00 & 0.50 & 0.00 & 2.19 & 0.09 & - \\
\hline Tetragnatha ilavaca & 0.00 & 0.33 & 0.50 & 0.67 & 0.00 & 0.00 & 3.29 & 0.02 & - \\
\hline Tetragnatha javana & 2.67 & 2.33 & 1.83 & 2.00 & 1.50 & 1.50 & 1.52 & 0.21 & - \\
\hline Tetragnatha maxillosa & 0.67 & 0.67 & 0.50 & 0.33 & 0.33 & 0.00 & 1.06 & 0.40 & - \\
\hline Tetragnatha okumae & 1.33 & 0.83 & 0.33 & 0.50 & 0.83 & 0.83 & 1.42 & 0.43 & - \\
\hline Tetragnatha vermivormis & 0.67 & 0.50 & 1.17 & 0.33 & 1.00 & 0.33 & 1.18 & 0.35 & - \\
\hline Tetragnatha virescens & 0.50 & 0.50 & 0.67 & 0.50 & 1.00 & 0.33 & 0.73 & 0.61 & - \\
\hline Theridiidae & 0.00 & 0.17 & 0.17 & 0.00 & 0.00 & 0.00 & 0.76 & 0.58 & - \\
\hline Coleosoma octomaculatum & 0.00 & 0.17 & 0.17 & 0.00 & 0.00 & 0.00 & 0.76 & 0.58 & - \\
\hline Thomisidae & 0.17 & 0.67 & 0.83 & 0.67 & 0.33 & 0.33 & 1.02 & 0.43 & - \\
\hline Thomisidae sp. A & 0.00 & 0.33 & 0.17 & 0.33 & 0.00 & 0.00 & 1.27 & 0.30 & - \\
\hline Thomisus sp. & 0.17 & 0.33 & 0.67 & 0.33 & 0.33 & 0.33 & 0.52 & 0.76 & - \\
\hline Total of abundance $(\mathbf{N})$ & $11.83^{\mathrm{b}}$ & $11.00^{\mathrm{b}}$ & $10.67^{\mathrm{b}}$ & $10.17^{\mathrm{b}}$ & $9.83^{b}$ & $5.17^{\mathrm{a}}$ & 11.68 & 0.00 & 0.45 \\
\hline Total of species $(\mathbf{S})$ & 17 & 24 & 21 & 18 & 16 & 13 & & & \\
\hline
\end{tabular}

Note: *: significantly different; values within a row followed by the same letters were not significantly different at $\mathrm{P}<0.05$ according to Tukey's HSD test 
All parasitoid species found were 12 species (Table 3 ). The dominant parasitoid species were found, among others Gonatocerus ashmeadi, Netomocera minuta, Snellenius manilae, Xanthopimpla punctata. The number of species found showed a decrease in bioinsecticide plots at a dose of 4 L.ha $^{-1}$ and abamectin. The lowest number of parasitoid species was found in the abamectin plot, which was only 3 species (Helorus anomalipes, Pteromalus sp., and Stictopisthus sp.), however, the abundance were not significantly different compared to the other plots.

There were 22 species of herbivores found throughout the paddies (Table 4). The dominant herbivores species were found, among others Leptocorisa acuta, Nephotetix virences, Spodoptera litura, Nilaparvata lugens, Pelopidas mathias. The number of herbivores species found in plots applied with bioinsecticide doses of 3 and 4 L.ha ${ }^{-1}$ and abamectin was lower than those applied with bioinsecticide doses of 1 and 2 L.ha ${ }^{-1}$, and control (without insecticide). There were 5 species of neutral insects and the dominant ones were Chironomus plumosus, Tipula maxima (Table 5 ). The number of species found in each treatment showed an almost equal number of 4-5 species. Figure 1 showed some arthropods found in this study.
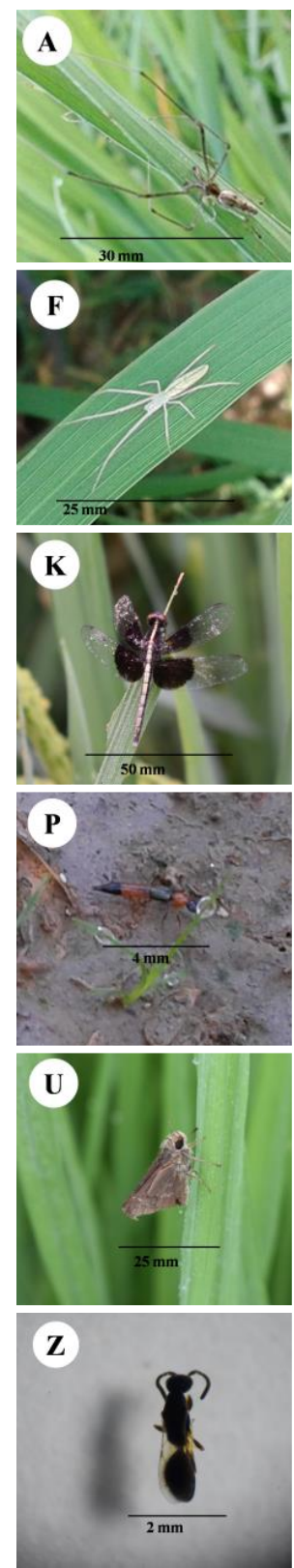
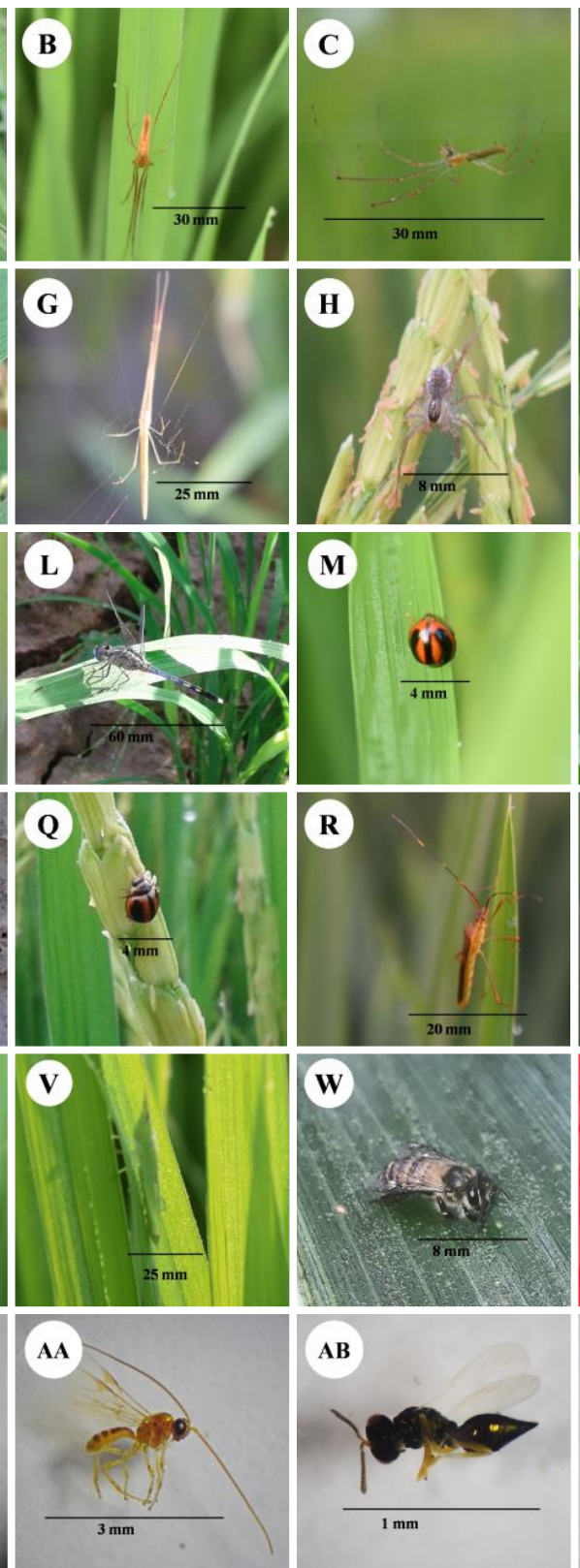
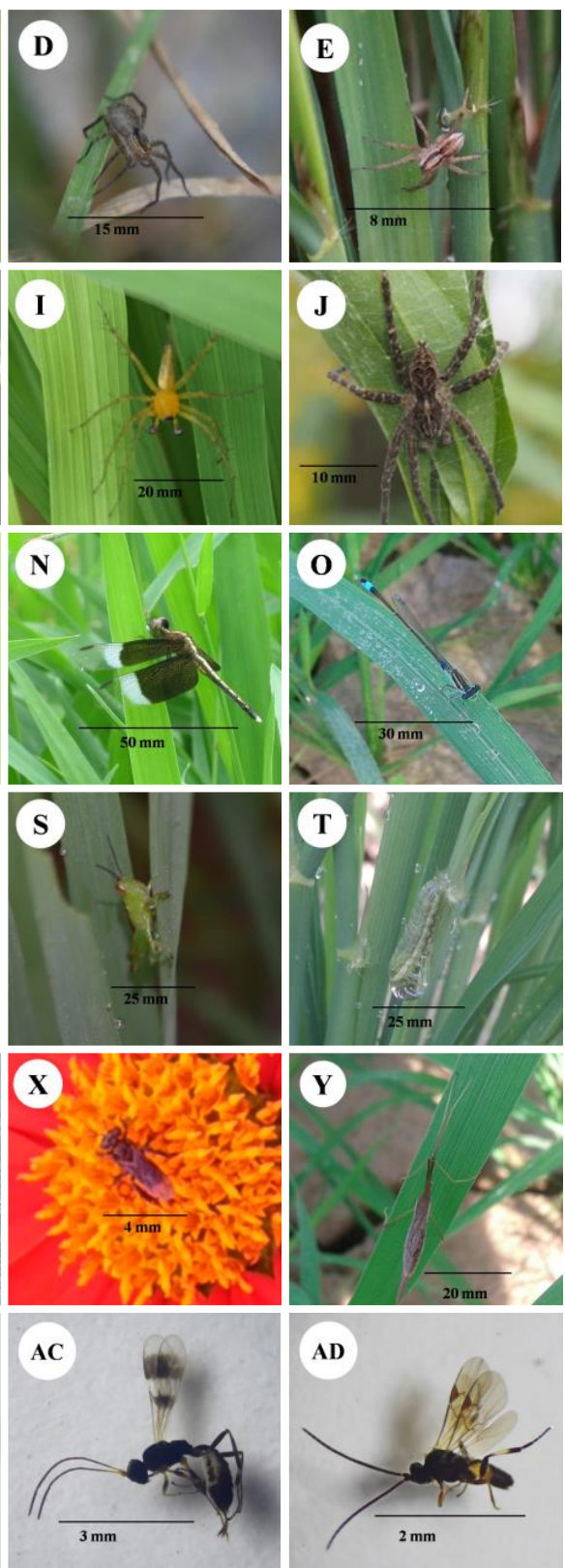

Figure 1. Arthropods found on paddy field of this research: Tetragnatha virescens (A), Tetragnatha vermivormis (B), Tetragnatha ilavaca (C), Pardosa pseudoannulata (D), Pardosa sumatrana (E), Tetragnatha maxillosa (F), Tetragnatha javana (G), Pardosa birmanica $(\mathrm{H})$, Oxyopes javanus (I), Pardosa pulata (J), Libellula sp. (K), Orthetrum sabina (L), Micraspis inops (M), Libellula luctuosa $(\mathrm{N})$, Ischnura senegalensis (O), Paederus fuscipes (P), Verania lineata (Q), Leptocorisa acuta (R), Valanga nigricornis $(\mathrm{S})$, Spodoptera litura (T), Pelopidas mathias (U), Acrida turrita (V), Apidae (W), Trigona sp. (X), Tipula maxima (Y), Hemiptarsenus anementus (Z), Xanthopimpla punctata (AA), Pteromalus sp. (AB), Stictopisthus sp. (AC), Snellenius manila (AD) 


\section{Abundance of arthropods in paddy applied with bioinsecticide}

The total data of the abundance of predators consisting of spiders and predatory insects showed that the spider abundance significantly decreases in total abundance of all species on plots applied with abamectin; yet, on plots applied with bioinsecticide doses of 1-4 L.ha ${ }^{-1}$ and control without insecticide, there was no significant decrease in total spider abundance (Table 1). A decrease in total abundance in one family was due to the application of abamectin found in Lycosidae and Salticidae. The abundance of predatory insects did not decrease in the plots applied with bioinsecticide, abamectin, and control (Table 2).

The parasitoid abundance of Hymenoptera order decreased significantly when abamectin was applied but the parasitoid abundance applied with bioinsecticide was not significantly different from that of the control (Table 3 ). The lowest abundance of parasitoids was found in the plot which was applied with abamectin, only one was found during one paddy planting season.

The abundance of herbivores in plots applied with bioinsecticide and abamectin decreased significantly when compared to those of the controls (Table 4). From the bioinsecticide field, there were found Pelopidas mathias larvae parasitized by $B$. bassiana (Figure 2). The families that had abundance decreased significantly were Noctuidae (Spodoptera litura) and Acrididae. The abundance of Spodoptera litura decreased when the bioinsecticide dose was applied $2{\mathrm{~L} . h \mathrm{C}^{-1}}^{-1}$ and it was not significantly different from the dose of 3 and L.ha ${ }^{-1}$. Therefore, the dosage of bioinsecticide $2 \mathrm{~L}^{-\mathrm{ha}^{-1}}$ was able to reduce the abundance of S. litura.

Table 2. Predatory insect abundance inhabiting on the paddy applied with bioinsecticide of Beauveria bassiana, control without treatment $\left(0 \mathrm{~L} . h a^{-1}\right)$, and abamectin

\begin{tabular}{|c|c|c|c|c|c|c|c|c|c|}
\hline \multirow{3}{*}{ Ordo/family/species } & \multicolumn{6}{|c|}{ Mean of abundance (individuals/5 nets) } & \multirow{3}{*}{$\begin{array}{c}\text { ANOVA } \\
\text { F-value }\end{array}$} & \multirow{3}{*}{ P value } & \multirow{3}{*}{$\begin{array}{l}\text { Tukey's } \\
\text { HSD test }\end{array}$} \\
\hline & \multicolumn{5}{|c|}{ Beauveria bassiana (L.ha-1) } & \multirow{2}{*}{ Abamectin } & & & \\
\hline & $\mathbf{0}$ & 1 & 2 & 3 & 4 & & & & \\
\hline COLEOPTERA & 5.50 & 3.67 & 5.00 & 4.00 & 3.50 & 3.33 & 2.07 & 0.10 & - \\
\hline Coccinellidae & 2.00 & 1.50 & 1.33 & 1.00 & 0.83 & 0.83 & 2.35 & 0.07 & - \\
\hline Micrapis inops & 1.17 & 0.83 & 0.83 & 0.83 & 0.67 & 0.67 & 0.63 & 0.67 & - \\
\hline Verania discolor & 0.00 & 0.17 & 0.00 & 0.00 & 0.00 & 0.00 & 1.00 & 0.43 & - \\
\hline Verania lineata & 0.83 & 0.50 & 0.50 & 0.17 & 0.17 & 0.17 & 1.40 & 0.25 & - \\
\hline Carabidae & 1.67 & 1.00 & 2.33 & 1.67 & 1.33 & 1.17 & 1.13 & 0.35 & - \\
\hline Ophionea nigrofasciata & 1.67 & 1.00 & 2.33 & 1.67 & 1.33 & 1.17 & 1.13 & 0.35 & - \\
\hline Staphylinidae & 1.83 & 1.17 & 1.33 & 1.33 & 1.33 & 1.33 & 0.40 & 0.83 & - \\
\hline Paederus fuscipes & 1.50 & 1.17 & 1.17 & 1.00 & 1.33 & 1.00 & 0.03 & 0.90 & - \\
\hline Paederus tamulus & 0.33 & 0.00 & 0.17 & 0.33 & 0.00 & 0.33 & 0.92 & 0.48 & - \\
\hline HYMENOPTERA & 1.50 & 1.50 & 1.50 & 1.67 & 1.17 & 1.33 & 0.22 & 0.94 & - \\
\hline Formicidae & 1.50 & 1.50 & 1.33 & 1.67 & 1.17 & 1.33 & 0.25 & 0.93 & - \\
\hline Crematogaster $\mathrm{sp}$. & 0.00 & 0.17 & 0.33 & 0.17 & 0.33 & 0.17 & 0.54 & 0.74 & - \\
\hline Monomorium destructor & 0.50 & 0.33 & 0.00 & 0.33 & 0.00 & 0.00 & 1.38 & 0.26 & - \\
\hline Odontponera transversa & 0.00 & 0.17 & 0.17 & 0.17 & 0.00 & 0.00 & 0.65 & 0.66 & - \\
\hline Solenopsis sp. & 1.00 & 0.83 & 0.83 & 1.00 & 0.83 & 1.17 & 0.19 & 0.96 & - \\
\hline Vespidae & 0.00 & 0.00 & 0.17 & 0.00 & 0.00 & 0.00 & 1.00 & 0.43 & - \\
\hline Ropalidia cyathiformis & 0.00 & 0.00 & 0.17 & 0.00 & 0.00 & 0.00 & 1.00 & 0.43 & - \\
\hline ODONATA & 1.67 & 1.50 & 1.00 & 0.50 & 0.83 & 0.67 & 1.16 & 0.35 & - \\
\hline Coenagrionidae & 0.17 & 0.00 & 0.33 & 0.00 & 0.00 & 0.17 & 1.31 & 0.28 & - \\
\hline Ischnura senegalensis & 0.17 & 0.00 & 0.33 & 0.00 & 0.00 & 0.17 & 1.31 & 0.29 & - \\
\hline Libellulidae & 1.50 & 1.50 & 0.67 & 0.50 & 0.83 & 0.50 & 1.16 & 0.35 & - \\
\hline Libellula sp. & 0.50 & 0.67 & 0.17 & 0.17 & 0.17 & 0.00 & 1.20 & 0.33 & - \\
\hline Libellula luctuosa & 0.33 & 0.17 & 0.33 & 0.00 & 0.17 & 0.50 & 1.41 & 0.25 & - \\
\hline Neurothemis fluctuans & 0.17 & 0.33 & 0.00 & 0.33 & 0.17 & 0.00 & 0.83 & 0.53 & - \\
\hline Ortetrum sabina & 0.17 & 0.17 & 0.17 & 0.00 & 0.17 & 0.00 & 0.40 & 0.84 & - \\
\hline Ortetrum testaceum & 0.33 & 0.17 & 0.00 & 0.00 & 0.17 & 0.00 & 1.13 & 0.36 & - \\
\hline ORTHOPTERA & 0.33 & 0.83 & 0.33 & 0.33 & 0.00 & 0.00 & 2.30 & 0.07 & - \\
\hline Mantidae & 0.17 & 0.67 & 0.33 & 0.33 & 0.00 & 0.00 & 1.70 & 0.17 & - \\
\hline Mantis religiosa & 0.17 & 0.33 & 0.17 & 0.33 & 0.00 & 0.00 & 0.83 & 0.53 & - \\
\hline Mantis sp. & 0.00 & 0.33 & 0.17 & 0.00 & 0.00 & 0.00 & 1.84 & 0.14 & - \\
\hline Tettigoniidae & 0.17 & 0.17 & 0.00 & 0.00 & 0.00 & 0.00 & 0.76 & 0.58 & - \\
\hline Conocepahalus longipenis & 0.17 & 0.17 & 0.00 & 0.00 & 0.00 & 0.00 & 0.76 & 0.58 & - \\
\hline Total of abundance $(\mathbf{N})$ & 9.00 & 7.50 & 7.83 & 6.50 & 5.50 & 5.33 & 2.26 & 0.08 & - \\
\hline Total of species $(\mathbf{S})$ & 15 & 18 & 15 & 12 & 11 & 9 & & & \\
\hline
\end{tabular}

Note: $*$ = significantly different; values within a row followed by the same letters were not significantly different at $\mathrm{P}<0.05$ according to Tukey's HSD test. 
Table 3. Parasitoid abundance inhabiting on the paddy applied with bioinsecticide of Beauveria bassiana, control without treatment $(0$ L.ha ${ }^{-1}$ ), and abamectin

\begin{tabular}{|c|c|c|c|c|c|c|c|c|c|}
\hline \multirow{3}{*}{ Ordo/family/species } & \multicolumn{6}{|c|}{ Mean of abundance (individuals/5 nets) } & \multirow{3}{*}{$\begin{array}{c}\text { ANOVA } \\
\text { F-value }\end{array}$} & \multirow{3}{*}{$\begin{array}{c}P \\
\text { value }\end{array}$} & \multirow{3}{*}{$\begin{array}{c}\text { Tukey's } \\
\text { HSD test }\end{array}$} \\
\hline & \multicolumn{5}{|c|}{ Beauveria bassiana (L.ha-1) } & \multirow{2}{*}{ Abamectin } & & & \\
\hline & $\mathbf{0}$ & 1 & 2 & 3 & 4 & & & & \\
\hline DIPTERA & 0.34 & 0.67 & 0.17 & 0.17 & 0 & 0 & 1.85 & 0.14 & - \\
\hline Tachinidae & 0.34 & 0.5 & 0.17 & 0.17 & 0 & 0 & 1.31 & 0.29 & - \\
\hline Athrycia sp. & 0 & 0.17 & 0 & 0 & 0 & 0 & 1 & 0.44 & - \\
\hline Blondelia nigripes & 0.17 & 0.33 & 0.17 & 0 & 0 & 0 & 1.14 & 0.37 & - \\
\hline Sarcophaga haemorrhoidalis & 0.17 & 0 & 0 & 0.17 & 0 & 0 & 1 & 0.44 & - \\
\hline Dolichopodidae & 0 & 0.17 & 0 & 0 & 0 & 0 & 1 & 0.44 & - \\
\hline Neurigona $\mathrm{sp}$ & 0 & 0.17 & 0 & 0 & 0 & 0 & 1 & 0.44 & - \\
\hline HYMENOPTERA & $3.84^{\mathrm{b}}$ & $3.17 \mathrm{ab}$ & $2.51^{\mathrm{ab}}$ & $2.17^{\mathrm{ab}}$ & $1.67^{\mathrm{ab}}$ & $1^{\mathrm{a}}$ & 2.73 & 0.04 & 2.69 \\
\hline Eulopidae & 0.17 & 0.17 & 0 & 0 & 0 & 0 & 0.77 & 0.58 & - \\
\hline Hemiptarsenus anementus & 0.17 & 0.17 & 0 & 0 & 0 & 0 & 0.77 & 0.58 & - \\
\hline Herolidae & 0.83 & 0.5 & 0.5 & 0.17 & 0.33 & 0.5 & 0.71 & 0.62 & - \\
\hline Helorus anomalipes & 0.83 & 0.5 & 0.5 & 0.17 & 0.33 & 0.5 & 0.71 & 0.62 & - \\
\hline Mymaridae & 0.83 & 0.33 & 0.17 & 0.17 & 0 & 0 & 2.33 & 0.07 & - \\
\hline Gonatocerus ashmeadi & 0.83 & 0.33 & 0.17 & 0.17 & 0 & 0 & 2.33 & 0.07 & - \\
\hline Pteromalidae & 0.84 & 1.5 & 1.17 & 1.33 & 0.67 & 0.33 & 1.16 & 0.36 & - \\
\hline Pteromalus sp. & 0.17 & 0.83 & 1 & 1 & 0.5 & 0.33 & 1.08 & 0.40 & - \\
\hline Netomocera minuta & 0.67 & 0.67 & 0.17 & 0.33 & 0.17 & 0 & 2.33 & 0.07 & - \\
\hline Ichneumonidae & 0.5 & 0.5 & 0.5 & 0.5 & 0.34 & 0.17 & 0.34 & 0.88 & - \\
\hline Xanthopimpla punctata & 0.33 & 0.17 & 0.33 & 0.17 & 0.17 & 0 & 0.59 & 0.71 & - \\
\hline Stictopisthus sp. & 0.17 & 0.33 & 0.17 & 0.33 & 0.17 & 0.17 & 0.23 & 0.95 & - \\
\hline Braconidae & 0.67 & 0.17 & 0.17 & 0 & 0.33 & 0 & 1.85 & 0.14 & - \\
\hline Snellenius manilae & 0.67 & 0.17 & 0.17 & 0 & 0.33 & 0 & 1.85 & 0.14 & - \\
\hline Total of abundance (N) & $4.18^{\mathrm{b}}$ & $3.84^{\mathrm{ab}}$ & $2.68^{\mathrm{ab}}$ & $2.34^{\mathrm{ab}}$ & $1.67^{\mathrm{ab}}$ & $1^{\mathrm{a}}$ & 3.47 & 0.02 & 2.86 \\
\hline Total of species $(\mathbf{S})$ & 10 & 11 & 8 & 7 & 6 & 3 & & & \\
\hline
\end{tabular}

Note: $*$ = significantly different; values within a row followed by the same letters were not significantly different at $\mathrm{P}<0.05$ according to Tukey's HSD test

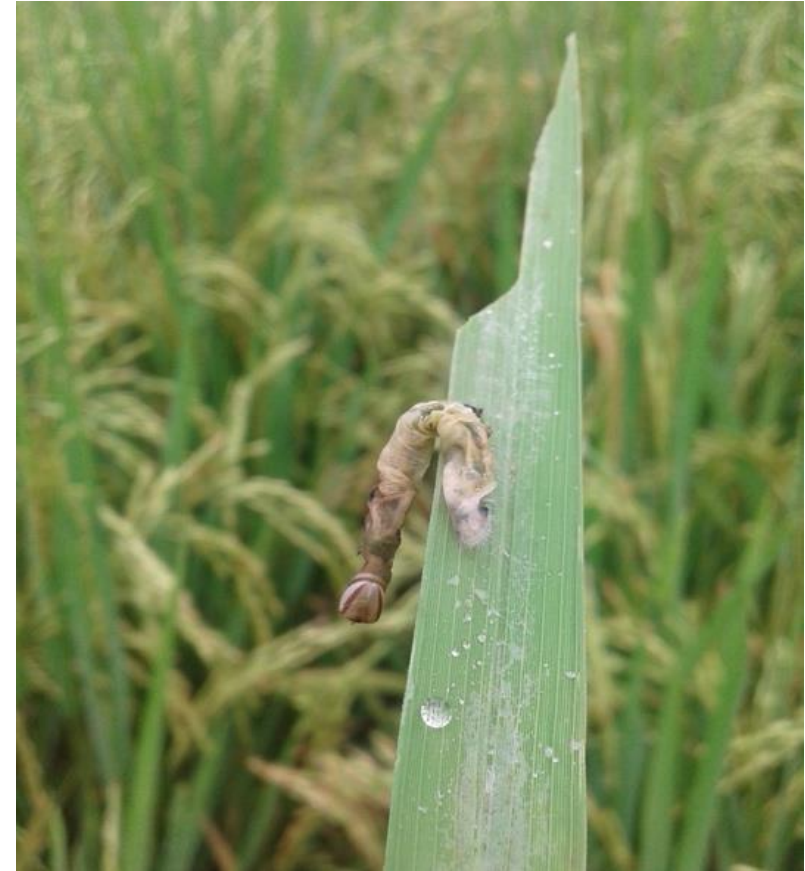

Figure 2. An insect pest, Pelopidas mathias infected by Beauveria bassiana on paddy field
The neutral insects did not experience a decrease in total abundance in the bioinsecticide, abamectin, and control plots, but the Diptera order decreased its abundance in the plots applied with bioinsecticide and abamectin (Table 5). There were 5 species of neutral insects found in this study generally acting as pollinators, organic matterdecomposer, and alternative prey for spiders.

Based on the comparison of abundance among the guilds (predators, parasitoids, herbivores, and neutral insects) the abundance of all guilds in plots applied with abamectin tended to be lower compared to control plots and bioinsecticides (Figure 3). The abundance of neutral insects and parasitoids from the beginning of planting before harvest is always lower than other guilds. The most ideal abundance of predators was shown to be much higher than the that of herbivores (predator's main prey) on control plots and plots applied with doses of 1 and 2 bioinsecticides, whereas in plots doses of 3 and 4 L.ha ${ }^{-1}$ and abamectin abundance of predators drastically decreased in herbivores abundance as well. Thus, the bioinsecticide in doses of 3 and 4 L.ha ${ }^{-1}$ and abamectin in addition to reducing the abundance of herbivores reduced the abundance of arthropods that were not targeted (predator). 

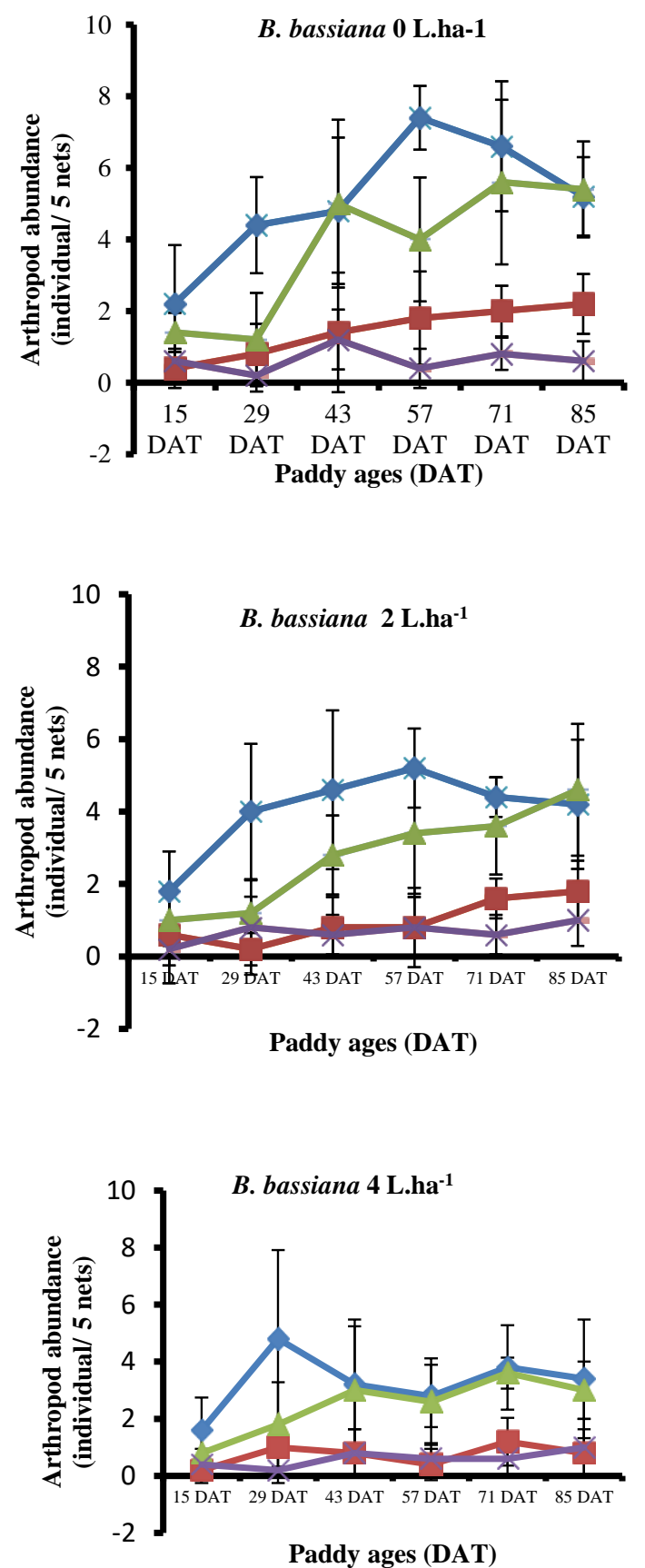

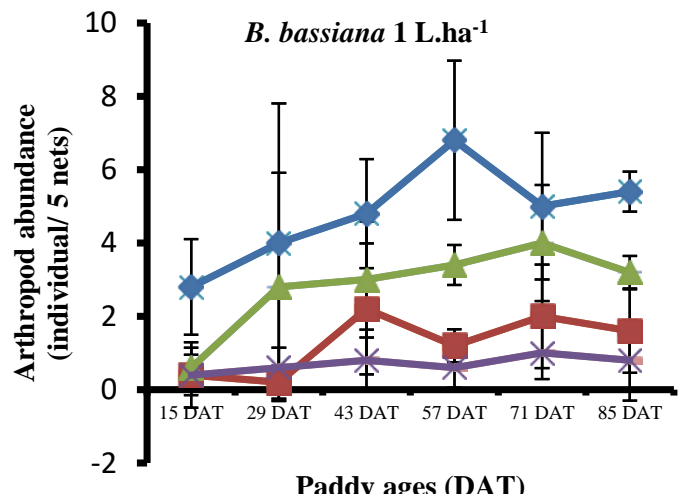

Paddy ages (DAT)
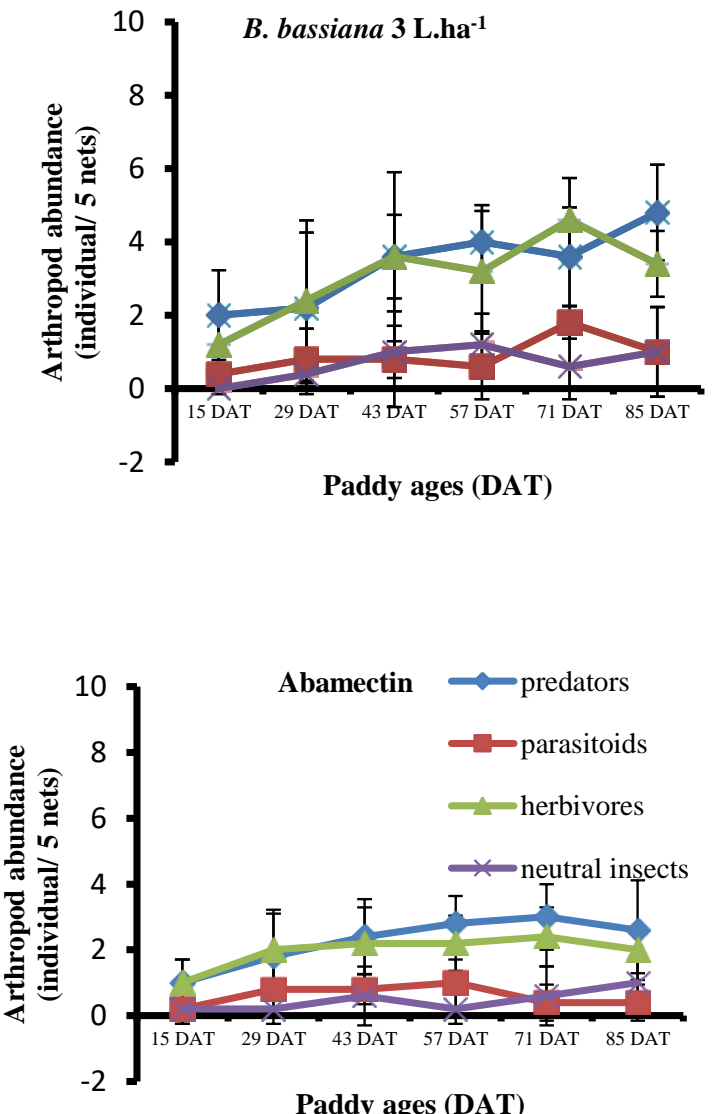

Figure 3. Arthropod abundance on the paddy applied with bioinsecticide of Beauveria bassiana, control without treatment $\left(0\right.$ L.ha $\left.{ }^{-1}\right)$, and abamectin, DAT $=$ days after transplanting

\section{Characteristics of the arthropods community in paddy with bioinsecticide application}

The species diversity (on average) was higher for spiders found in control plots applied with bioinsecticide in doses of 1 and 2 L.ha $^{-1}$ compared to bioinsecticide plots of 3 and 4 L.ha $^{-1}$ and abamectin (Table 6); still, the domination of spider species was not found in all plots. The decreased diversity of species predatory insects began to occur in plots applied with bioinsecticide in doses of 2, 3, and 4 L.ha $^{-1}$ and abamectin (Table 7). The lowest diversity of predatory insect species was found in the abamectin plot.

Parasitoid species diversity (on average) decreased in plots applied with bioinsecticide doses of 2, 3, and 4 L.ha- ${ }^{-1}$ and abamectin (Table 8). In all plots, there were no species of domination found. On the contrary, the diversity of herbivores species (on average) was higher in the plots applied with bioinsecticide doses of 3 and 4 L.ha ${ }^{-1}$. However, in all of these plots, there was no domination of herbivores species (Table 9). The decrease in diversity of species neutral insects were found in the plots applied with bioinsecticides in doses of 2, 3, 4 L.ha ${ }^{-1}$ and abamectin; yet, no species dominance was found (Table 10). In addition, the abundance of neutral insects in all plots was lower than the abundance of other guilds. 
Table 4. Insect pest or herbivore abundance inhabiting on the paddy applied with bioinsecticide of Beauveria bassiana, control without

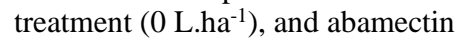

\begin{tabular}{|c|c|c|c|c|c|c|c|c|c|}
\hline \multirow{3}{*}{ Ordo/family/species } & \multicolumn{6}{|c|}{ Mean of abundance (individuals/5 nets) } & \multirow{3}{*}{$\begin{array}{l}\text { ANOVA } \\
\text { F-value }\end{array}$} & \multirow{3}{*}{$\begin{array}{c}\mathbf{P} \\
\text { value }\end{array}$} & \multirow{3}{*}{$\begin{array}{c}\text { Tukey's } \\
\text { HSD } \\
\text { test }\end{array}$} \\
\hline & \multicolumn{5}{|c|}{ Beauveria bassiana (L.ha-1) } & \multirow{2}{*}{ Abamectin } & & & \\
\hline & $\mathbf{0}$ & 1 & 2 & 3 & 4 & & & & \\
\hline \multicolumn{10}{|l|}{ COLEOPTERA } \\
\hline Coccinelidae & 0.50 & 0.17 & 0.17 & 0.17 & 0.33 & 0.00 & 1.29 & 0.20 & - \\
\hline Thea vigintiduopunctata & 0.50 & 0.17 & 0.17 & 0.17 & 0.33 & 0.00 & 1.29 & 0.20 & - \\
\hline Crisomelidae & 0.33 & 0.33 & 0.17 & 0.00 & 0.33 & 0.17 & 0.57 & 0.71 & - \\
\hline Dicladispa armigera & 0.33 & 0.33 & 0.17 & 0.00 & 0.33 & 0.17 & 0.57 & 0.71 & - \\
\hline \multicolumn{10}{|l|}{ DIPTERA } \\
\hline Cecidomyiidae & 0.50 & 0.50 & 0.17 & 0.33 & 0.17 & 0.50 & 0.57 & 0.72 & - \\
\hline Orselia sp. & 0.50 & 0.50 & 0.17 & 0.33 & 0.17 & 0.50 & 0.57 & 0.72 & - \\
\hline \multicolumn{10}{|l|}{ HEMIPTERA } \\
\hline Alydidae & 2.50 & 1.83 & 2.17 & 2.00 & 1.67 & 1.17 & 1.33 & 0.28 & - \\
\hline Leptocorisa acuta & 2.50 & 1.83 & 2.17 & 2.00 & 1.67 & 1.17 & 1.33 & 0.28 & - \\
\hline Cicadelidae & 1.67 & 1.50 & 1.67 & 1.83 & 1.33 & 0.83 & 1.68 & 0.17 & - \\
\hline Nephotetix virences & 1.67 & 1.50 & 1.67 & 1.83 & 1.33 & 0.83 & 1.36 & 0.27 & - \\
\hline Coreidae & 0.33 & 0.33 & 0.17 & 0.17 & 0.00 & 0.17 & 0.54 & 0.74 & - \\
\hline Alydus eurinus & 0.17 & 0.00 & 0.00 & 0.17 & 0.00 & 0.17 & 0.55 & 0.73 & - \\
\hline Cletus trigonus & 0.17 & 0.33 & 0.17 & 0.00 & 0.00 & 0.00 & 1.13 & 0.36 & - \\
\hline Delphacidae & $0.67^{\mathrm{ab}}$ & $1.33^{\mathrm{ab}}$ & $0.50^{\mathrm{a}}$ & $2.33^{\mathrm{b}}$ & $1.17^{\mathrm{ab}}$ & $0.67^{\mathrm{ab}}$ & 2.57 & 0.05 & 0.52 \\
\hline Nilaparvata lugens & $0.67^{\mathrm{ab}}$ & $1.33^{\mathrm{ab}}$ & $0.50^{\mathrm{a}}$ & $2.33^{\mathrm{b}}$ & $1.17^{\mathrm{ab}}$ & $0.67^{\mathrm{ab}}$ & 2.57 & 0.05 & 0.52 \\
\hline Pentatomidae & 0.00 & 0.33 & 0.50 & 0.17 & 0.33 & 0.50 & 0.80 & 0.55 & - \\
\hline Nezara viridula & 0.00 & 0.33 & 0.50 & 0.17 & 0.33 & 0.50 & 0.80 & 0.55 & - \\
\hline \multicolumn{10}{|l|}{ LEPIDOPTERA } \\
\hline Hesperiidae & 0.17 & 0.00 & 0.50 & 0.17 & 0.17 & 0.17 & 0.92 & 0.48 & - \\
\hline Parnara guttata & 0.00 & 0.00 & 0.33 & 0.17 & 0.17 & 0.00 & 1.00 & 0.43 & - \\
\hline Pelopidas mathias & 0.17 & 0.00 & 0.17 & 0.00 & 0.00 & 0.17 & 0.55 & 0.73 & - \\
\hline Noctuidae & $2.33^{\mathrm{d}}$ & $2.00^{\mathrm{cd}}$ & $1.33^{\mathrm{bcd}}$ & $0.83^{\mathrm{abc}}$ & $0.67^{\mathrm{ab}}$ & $0.33^{\mathrm{a}}$ & 8.22 & 0.00 & 0.44 \\
\hline Spodoptera litura & $2.33^{\mathrm{d}}$ & $2.00^{\mathrm{cd}}$ & $1.33^{\mathrm{bcd}}$ & $0.83^{\mathrm{abc}}$ & $0.67^{\mathrm{ab}}$ & $0.33^{\mathrm{a}}$ & 8.22 & 0.00 & 0.44 \\
\hline \multicolumn{10}{|l|}{ ORTHOPTERA } \\
\hline Acrididae & $6.83^{\mathrm{b}}$ & $5.33^{\mathrm{ab}}$ & $6.00^{\mathrm{ab}}$ & $4.83^{\mathrm{ab}}$ & $4.00^{\mathrm{ab}}$ & $3.33^{\mathrm{a}}$ & 3.56 & 0.01 & 0.84 \\
\hline Oxya chinensis & 0.67 & 0.17 & 0.83 & 0.33 & 0.17 & 0.33 & 1.36 & 0.27 & - \\
\hline Acrida turrita & 1.00 & 0.33 & 1.00 & 0.33 & 0.33 & 0.50 & 1.48 & 0.23 & - \\
\hline Ailopus thalassinus & 0.67 & 0.50 & 0.50 & 0.67 & 0.17 & 0.50 & 0.44 & 0.81 & - \\
\hline Gesonula mundata & 0.00 & 0.50 & 0.33 & 0.00 & 0.17 & 0.00 & 2.05 & 0.10 & - \\
\hline Locusta migratoria & 1.50 & 1.67 & 1.17 & 1.50 & 1.17 & 0.67 & 2.11 & 0.10 & - \\
\hline Valanga nigricornis & 3.00 & 2.17 & 2.17 & 2.00 & 2.00 & 1.33 & 1.64 & 0.19 & - \\
\hline Gryllidae & 0.33 & 0.17 & 0.17 & 0.17 & 0.00 & 0.17 & 0.50 & 0.77 & - \\
\hline Gryllus bimaculatus & 0.33 & 0.17 & 0.17 & 0.17 & 0.00 & 0.17 & 0.50 & 0.77 & - \\
\hline Grylotalpidae & 0.17 & 0.17 & 0.00 & 0.00 & 0.00 & 0.00 & 1.00 & 0.43 & - \\
\hline Grylotalpa grylotalpa & 0.17 & 0.17 & 0.00 & 0.00 & 0.00 & 0.00 & 1.00 & 0.43 & - \\
\hline Tettigoniidae & 0.50 & 0.17 & 0.50 & 0.17 & 0.50 & 0.00 & 1.10 & 0.38 & - \\
\hline Neochonocephalus ensiger & 0.50 & 0.00 & 0.00 & 0.00 & 0.17 & 0.00 & 2.89 & 0.03 & - \\
\hline Tetrix subulata & 0.00 & 0.17 & 0.50 & 0.17 & 0.33 & 0.00 & 0.98 & 0.44 & - \\
\hline Total of abundance (N) & $16.83^{\mathrm{c}}$ & $14.17^{\mathrm{bc}}$ & $14.00^{\mathrm{bc}}$ & $13.17^{\mathrm{bc}}$ & $10.67^{\mathrm{ab}}$ & $8.01^{\mathrm{a}}$ & 10.36 & 0.00 & 0.55 \\
\hline Total of species $(\mathbf{S})$ & 18 & 18 & 19 & 16 & 17 & 15 & & & \\
\hline
\end{tabular}

Note: * = significantly different; values within a row followed by the same letters were not significantly different at $\mathrm{P}<0.05$ according to Tukey's HSD test

\section{Discussion}

The abundance of spiders and predatory arthropods did not decrease when bioinsecticides derived from B. bassiana were applied. The spiders and predatory arthropods were more resistant to $B$. bassiana and proved that $B$. bassiana did not adversely affect the predator. Many studies suggest that $B$. bassiana is a specific fungus that only kills insects from certain orders, such as Lepidoptera (Safitri et al. 2018; Ayudya et al. 2019) or Homoptera (Sumikarsih et al. 2019), whereas predators found in this study were spiders and insects of the order Coleoptera and Odonata, not those of the Order Lepidoptera or Homoptera. Entomopathogenic fungi are generally harmless to spiders (Yuliani 2016) and Coleoptera (Ngin et al. 2017). So, the application of the $B$. bassiana supported the existence of the spiders and predatory arthropods so that they are able to suppress insect pest populations which ultimately can support agroecosystem stability. Gholamzadeh-Chitgar et al. (2017) added that the B. bassiana did not harm the predators of brown planthoppers, for example, a predatory bug (Andrallus spinidens) of the Hemiptera order. 
Table 5. Neutral insect abundance in on the paddy applied with bioinsecticide of Beauveria bassiana, control without treatment (0 L.ha1), and abamectin

\begin{tabular}{|c|c|c|c|c|c|c|c|c|c|}
\hline \multirow{3}{*}{ Ordo/family/species } & \multicolumn{6}{|c|}{ Mean of abundance (individuals/5 nets) } & \multirow{3}{*}{$\begin{array}{c}\text { ANOVA } \\
\text { F-value }\end{array}$} & \multirow{3}{*}{$\begin{array}{c}P \\
\text { value }\end{array}$} & \multirow{3}{*}{$\begin{array}{c}\text { Tukey's } \\
\text { HSD } \\
\text { test }\end{array}$} \\
\hline & \multicolumn{5}{|c|}{ Beauveria bassiana (L.ha-1) } & \multirow{2}{*}{ Abamectin } & & & \\
\hline & $\mathbf{0}$ & 1 & 2 & 3 & 4 & & & & \\
\hline DIPTERA & $3.17 \mathrm{~b}$ & $2.00 \mathrm{ab}$ & $2.16 \mathrm{ab}$ & $2.66 \mathrm{ab}$ & $1.50 \mathrm{a}$ & $1.67 \mathrm{a}$ & 3.39 & 0.02 & 0.63 \\
\hline Chironomidae & 0.33 & 0.17 & 0.00 & 0.17 & 0.00 & 0.00 & 0.60 & 0.70 & - \\
\hline Chironomus plumosus & 0.33 & 0.17 & 0.00 & 0.17 & 0.00 & 0.00 & 0.60 & 0.70 & - \\
\hline Tipulidae & 2.00 & 1.33 & 1.83 & 1.83 & 1.33 & 1.17 & 1.58 & 0.20 & - \\
\hline Tipula maxima & 2.00 & 1.33 & 1.83 & 1.83 & 1.33 & 1.17 & 1.58 & 0.20 & - \\
\hline Culicidae & 0.83 & 0.50 & 0.33 & 0.67 & 0.17 & 0.50 & 0.68 & 0.64 & - \\
\hline Culex pipiens & 0.83 & 0.50 & 0.33 & 0.67 & 0.17 & 0.50 & 0.68 & 0.64 & - \\
\hline HYMENOPTERA & 0.50 & 1.17 & 0.83 & 0.67 & 1.17 & 1.17 & 1.15 & 0.36 & - \\
\hline Apidae & 0.50 & 1.17 & 0.83 & 0.67 & 1.17 & 1.17 & 1.15 & 0.36 & - \\
\hline Trigona sp. & 0.17 & 0.50 & 0.50 & 0.33 & 0.33 & 0.83 & 0.91 & 0.49 & - \\
\hline Apidae (unknown species) & 0.33 & 0.67 & 0.33 & 0.33 & 0.83 & 0.33 & 0.56 & 0.73 & - \\
\hline Total of abundance $(\mathbf{N})$ & 3.66 & 3.17 & 2.99 & 3.33 & 2.66 & 2.83 & 1.09 & 0.39 & - \\
\hline Total of species $(\mathbf{S})$ & 5 & 5 & 4 & 5 & 4 & 4 & & & \\
\hline
\end{tabular}

Note: $*$ = significantly different; values within a row followed by the same letters were not significantly different at $\mathrm{P}<0.05$ according to Tukey's HSD test

Table 6. Community characteristics of spiders inhabiting on the paddy applied with bioinsecticide of Beauveria bassiana, control

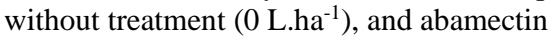

\begin{tabular}{|c|c|c|c|c|c|c|c|}
\hline \multirow{2}{*}{$\begin{array}{l}\text { Paddy age } \\
\text { (days) }\end{array}$} & \multirow{2}{*}{ Community characteristics } & \multicolumn{5}{|c|}{ Beauveria bassiana L.ha-1 } & \multirow{2}{*}{ Abamectin } \\
\hline & & $\mathbf{0}$ & 1 & 2 & 3 & 4 & \\
\hline \multirow{4}{*}{15} & Number of individual (individuals/5 nets) & 5 & 7 & 5 & 9 & 6 & 1 \\
\hline & Diversity (H') & 1.61 & 1.95 & 1.61 & 1.55 & 1.56 & 0.00 \\
\hline & Dominance (D) & 0.20 & 0.14 & 0.20 & 0.22 & 0.33 & 1.00 \\
\hline & Evenness (E) & 1.00 & 1.00 & 1.00 & 0.75 & 0.97 & 0.00 \\
\hline \multirow{4}{*}{29} & Number of individual (individuals $/ 5$ nets) & 10 & 11 & 10 & 8 & 10 & 3 \\
\hline & Diversity (H') & 2.03 & 2.10 & 2.03 & 1.91 & 2.16 & 1.10 \\
\hline & Dominance (D) & 0.20 & 0.27 & 0.20 & 0.25 & 0.20 & 0.33 \\
\hline & Evenness (E) & 0.97 & 0.95 & 0.97 & 0.98 & 0.98 & 1.00 \\
\hline \multirow{4}{*}{43} & Number of individual (individuals/5 nets) & 13 & 9 & 15 & 8 & 9 & 4 \\
\hline & Diversity (H') & 1.95 & 2.20 & 1.71 & 1.32 & 1.74 & 1.39 \\
\hline & Dominance (D) & 0.23 & 0.11 & 0.27 & 0.38 & 0.22 & 0.25 \\
\hline & Evenness (E) & 0.94 & 1.00 & 0.96 & 0.95 & 0.97 & 1.00 \\
\hline \multirow{4}{*}{57} & Number of individual (individuals $/ 5$ nets) & 16 & 19 & 12 & 10 & 8 & 7 \\
\hline & Diversity (H') & 2.17 & 2.63 & 2.09 & 1.83 & 1.21 & 1.27 \\
\hline & Dominance (D) & 0.25 & 0.16 & 0.25 & 0.30 & 0.25 & 0.29 \\
\hline & Evenness (E) & 0.94 & 0.97 & 0.95 & 0.94 & 0.68 & 0.79 \\
\hline \multirow{4}{*}{71} & Number of individual (individuals/5 nets) & 14 & 10 & 9 & 14 & 9 & 7 \\
\hline & Diversity (H') & 2.04 & 2.03 & 1.52 & 1.97 & 1.89 & 1.07 \\
\hline & Dominance (D) & 0.29 & 0.20 & 0.33 & 0.21 & 0.22 & 0.29 \\
\hline & Evenness (E) & 0.93 & 0.97 & 0.95 & 0.95 & 0.97 & 0.77 \\
\hline \multirow{4}{*}{85} & Number of individual (individuals/5 nets) & 9 & 10 & 13 & 12 & 17 & 9 \\
\hline & Diversity (H') & 1.74 & 1.97 & 1.74 & 1.98 & 1.87 & 1.37 \\
\hline & Dominance (D) & 0.22 & 0.30 & 0.23 & 0.25 & 0.24 & 0.33 \\
\hline & Evenness (E) & 0.97 & 0.95 & 0.97 & 0.95 & 0.96 & 0.99 \\
\hline \multirow{4}{*}{ Mean } & Number of individual (individuals $/ 5$ nets) & 11.83 & 11.00 & 10.67 & 10.17 & 9.83 & 5.17 \\
\hline & Diversity (H') & 2.53 & 2.88 & 2.81 & 2.65 & 2.60 & 2.25 \\
\hline & Dominance (D) & 0.22 & 0.21 & 0.17 & 0.20 & 0.15 & 0.29 \\
\hline & Evenness (E) & 0.89 & 0.91 & 0.92 & 0.92 & 0.94 & 0.88 \\
\hline
\end{tabular}

The abundance of spiders, especially Lycosidae and Salticidae, decreased significantly when applied with commercial insecticides from the active ingredient abamectin. The data were in line with the research results of Prabawati et al. (2019) who found that spider abundance dropped significantly when paddy was sprayed with abamectin. Abamectin is a broad-spectrum insecticide that can kill many species of arthropods (Ananiev et al. 2002). In addition, the abundance of the Hymenoptera parasitoid also decreased significantly when abamectin was applied. Sasmito et al. (2017) reported that abamectin could reduce the ability of the brown planthopper parasitoid (Anagrus nilaparvatae) in parasitizing and also reduced the abundance of these parasitoid offspring. 
Table 7. Community characteristics of predatory insects inhabiting on the paddy applied with bioinsecticide of Beauveria bassiana, control without treatment $\left(0{\left.\mathrm{~L} . h a^{-1}\right)}^{-1}\right.$ and abamectin

\begin{tabular}{|c|c|c|c|c|c|c|c|}
\hline \multirow{2}{*}{$\begin{array}{l}\text { Paddy age } \\
\text { (days) }\end{array}$} & \multirow{2}{*}{ Community characteristics } & \multicolumn{5}{|c|}{ Beauveria bassiana L.ha-1 } & \multirow[t]{2}{*}{ Abamectir } \\
\hline & & $\mathbf{0}$ & 1 & 2 & 3 & 4 & \\
\hline \multirow{4}{*}{15} & Number of individual (individuals/ 5 nets) & 4 & 5 & 2 & 3 & 2 & 2 \\
\hline & Diversity (H') & 1.39 & 1.61 & 0.69 & 1.10 & 0.69 & 0.69 \\
\hline & Dominance (D) & 0.25 & 0.20 & 0.50 & 0.33 & 0.50 & 0.50 \\
\hline & Evenness (E) & 1 & 1 & 1 & 1 & 1 & 1 \\
\hline \multirow{4}{*}{29} & Number of individual (individuals/ 5 nets) & 7 & 5 & 7 & 6 & 5 & 7 \\
\hline & Diversity (H') & 1.55 & 1.33 & 1.48 & 1.56 & 1.61 & 1.55 \\
\hline & Dominance (D) & 0.29 & 0.40 & 0.43 & 0.33 & 0.20 & 0.29 \\
\hline & Evenness (E) & 0.96 & 0.96 & 0.92 & 0.97 & 1.00 & 0.96 \\
\hline \multirow{4}{*}{43} & Number of individual (individuals/ 5 nets) & 8 & 8 & 9 & 5 & 6 & 5 \\
\hline & Diversity (H') & 1.91 & 2.08 & 2.20 & 1.61 & 1.80 & 1.61 \\
\hline & Dominance (D) & 0.25 & 0.13 & 0.11 & 0.20 & 0.17 & 0.20 \\
\hline & Evenness $(\mathrm{E})$ & 0.98 & 1.00 & 1.00 & 1.00 & 1.00 & 1.00 \\
\hline \multirow{4}{*}{57} & Number of individual (individuals/ 5 nets) & 11 & 11 & 7 & 9 & 7 & 7 \\
\hline & Diversity (H') & 2.15 & 2.40 & 1.95 & 2.04 & 1.95 & 1.75 \\
\hline & Dominance (D) & 0.18 & 0.09 & 0.14 & 0.22 & 0.14 & 0.29 \\
\hline & Evenness $(\mathrm{E})$ & 0.98 & 1.00 & 1.00 & 0.98 & 1.00 & 0.98 \\
\hline \multirow{4}{*}{71} & Number of individual (individuals/ 5 nets) & 12 & 9 & 11 & 8 & 7 & 6 \\
\hline & Diversity (H') & 2.37 & 2.20 & 2.15 & 1.91 & 1.75 & 1.56 \\
\hline & Dominance (D) & 0.17 & 0.11 & 0.18 & 0.25 & 0.29 & 0.33 \\
\hline & Evenness $(\mathrm{E})$ & 0.99 & 1.00 & 0.98 & 0.98 & 0.98 & 0.97 \\
\hline \multirow{4}{*}{85} & Number of individual (individuals/ 5 nets) & 12 & 7 & 11 & 8 & 6 & 5 \\
\hline & Diversity (H') & 1.84 & 1.67 & 2.15 & 1.65 & 1.79 & 1.29 \\
\hline & Dominance (D) & 0.17 & 0.14 & 0.18 & 0.25 & 0.17 & 0.20 \\
\hline & Evenness (E) & 0.80 & 0.86 & 0.98 & 0.85 & 1.00 & 0.80 \\
\hline \multirow{4}{*}{ Mean } & Number of individual (individuals/ 5 nets) & 9.00 & 7.50 & 7.83 & 6.50 & 5.50 & 5.33 \\
\hline & Diversity (H') & 2.40 & 2.59 & 2.28 & 2.17 & 2.04 & 1.96 \\
\hline & Dominance (D) & 0.19 & 0.16 & 0.30 & 0.26 & 0.24 & 0.22 \\
\hline & Evenness (E) & 0.89 & 0.91 & 0.84 & 0.88 & 0.85 & 0.89 \\
\hline
\end{tabular}

Table 8. Community characteristics of parasitoid inhabiting on the paddy applied with bioinsecticide of Beauveria bassiana, control without treatment $(0$ L.ha-1 $)$, and abamectin

\begin{tabular}{|c|c|c|c|c|c|c|c|}
\hline \multirow{2}{*}{$\begin{array}{c}\text { Paddy age } \\
\text { (days) }\end{array}$} & \multirow{2}{*}{ Community characteristics } & \multicolumn{5}{|c|}{ Beauveria bassiana L.ha $^{-1}$} & \multirow[t]{2}{*}{ Abamectin } \\
\hline & & $\mathbf{0}$ & 1 & 2 & $\mathbf{3}$ & 4 & \\
\hline \multirow{4}{*}{15} & Number of individual (individuals/ 5 nets) & 0 & 1 & 1 & 0 & 1 & 1 \\
\hline & Diversity (H') & 0 & 0 & 0 & 0 & 0 & 0 \\
\hline & Dominance (D) & 0 & 1 & 1 & 0 & 1 & 1 \\
\hline & Evenness (E) & 0 & 0 & 0 & 0 & 0 & 0 \\
\hline \multirow{4}{*}{29} & Number of individual (individuals/ 5 nets) & 1 & 0 & 1 & 1 & 2 & 1 \\
\hline & Diversity (H') & 0 & 0 & 0 & 0 & 0 & 0 \\
\hline & Dominance (D) & 1 & 0 & 1 & 1 & 1 & 1 \\
\hline & Evenness $(\mathrm{E})$ & 0 & 0 & 0 & 0 & 0 & 0 \\
\hline \multirow{4}{*}{43} & Number of individual (individuals/ 5 nets) & 5 & 6 & 2 & 2 & 0 & 1 \\
\hline & Diversity (H') & 1.33 & 1.33 & 0.69 & 0.69 & 0 & 0 \\
\hline & Dominance (D) & 0.4 & 0.33 & 0.5 & 0.5 & 0 & 1 \\
\hline & Evenness (E) & 0.96 & 0.96 & 1 & 1 & 0 & 0 \\
\hline \multirow{4}{*}{57} & Number of individual (individuals/ 5 nets) & 5 & 5 & 2 & 2 & 1 & 1 \\
\hline & Diversity (H') & 1.61 & 1.33 & 0.69 & 0.69 & 0 & 0 \\
\hline & Dominance (D) & 0.2 & 0.4 & 0.5 & 0.5 & 1 & 0 \\
\hline & Evenness (E) & 1 & 0.96 & 1 & 1 & 0 & 0 \\
\hline \multirow{4}{*}{71} & Number of individual (individuals/ 5 nets) & 6 & 6 & 2 & 5 & 3 & 1 \\
\hline & Diversity (H') & 1.79 & 1.79 & 0.69 & 1.05 & 0.64 & 0 \\
\hline & Dominance (D) & 0.17 & 0.17 & 0.5 & 0.4 & 0.67 & 1 \\
\hline & Evenness (E) & 1 & 1 & 1 & 0.96 & 0.92 & 0 \\
\hline \multirow{4}{*}{85} & Number of individual (individuals/ 5 nets) & 8 & 5 & 8 & 4 & 3 & 1 \\
\hline & Diversity (H') & 1.73 & 1.33 & 1.21 & 1.04 & 0.64 & 0 \\
\hline & Dominance (D) & 0.25 & 0.4 & 0.5 & 0.5 & 0.67 & 1 \\
\hline & Evenness (E) & 0.97 & 0.96 & 0.88 & 0.95 & 0.92 & 0 \\
\hline \multirow{4}{*}{ Mean } & Number of individual (individuals/ 5 nets) & 4.18 & 3.84 & 2.68 & 2.343 & 1.67 & 1 \\
\hline & Diversity (H') & 2.08 & 2.22 & 1.81 & 1.68 & 1.70 & 1.01 \\
\hline & Dominance (D) & 0.20 & 0.22 & 0.37 & 0.43 & 0.30 & 0.33 \\
\hline & Evenness (E) & 0.90 & 0.93 & 0.87 & 0.86 & 0.95 & 0 \\
\hline
\end{tabular}


Table 9. Community characteristics of insect pests inhabiting on the paddy applied with bioinsecticide of Beauveria bassiana, control without treatment $\left(0\right.$ L.ha $\left.{ }^{-1}\right)$, and abamectin

\begin{tabular}{|c|c|c|c|c|c|c|c|}
\hline \multirow{2}{*}{$\begin{array}{c}\text { Paddy age } \\
\text { (days) }\end{array}$} & \multirow{2}{*}{ Community characteristics } & \multicolumn{5}{|c|}{ Beauveria bassiana L.ha-1 } & \multirow[t]{2}{*}{ Abamectin } \\
\hline & & $\mathbf{0}$ & 1 & 2 & 3 & 4 & \\
\hline \multirow{4}{*}{15} & Number of individual (individuals/ 5 nets) & 5 & 7 & 5 & 4 & 7 & 7 \\
\hline & Diversity (H’) & 1.61 & 1.55 & 1.61 & 1.39 & 1.48 & 1.55 \\
\hline & Dominance (D) & 0.20 & 0.29 & 0.20 & 0.25 & 0.43 & 0.29 \\
\hline & Evenness $(\mathrm{E})$ & 1.00 & 0.96 & 1.00 & 1.00 & 0.92 & 0.96 \\
\hline \multirow{4}{*}{29} & Number of individual (individuals/ 5 nets) & 7 & 14 & 7 & 12 & 9 & 6 \\
\hline & Diversity (H') & 1.95 & 2.14 & 1.75 & 2.09 & 1.68 & 1.79 \\
\hline & Dominance (D) & 0.14 & 0.14 & 0.29 & 0.25 & 0.33 & 0.17 \\
\hline & Evenness (E) & 0.14 & 0.98 & 0.98 & 0.95 & 0.94 & 1.00 \\
\hline \multirow{4}{*}{43} & Number of individual (individuals/ 5 nets) & 21 & 14 & 18 & 15 & 11 & 11 \\
\hline & Diversity (H') & 2.18 & 2.54 & 2.06 & 2.40 & 2.40 & 2.27 \\
\hline & Dominance (D) & 0.29 & 0.14 & 0.17 & 0.20 & 0.09 & 0.18 \\
\hline & Evenness $(\mathrm{E})$ & 0.91 & 0.99 & 0.99 & 0.96 & 1.00 & 0.99 \\
\hline \multirow{4}{*}{57} & Number of individual (individuals/ 5 nets) & 21 & 17 & 17 & 12 & 13 & 6 \\
\hline & Diversity (H') & 2.29 & 2.51 & 1.89 & 2.25 & 1.99 & 1.79 \\
\hline & Dominance (D) & 0.19 & 0.12 & 0.29 & 0.17 & 0.23 & 0.17 \\
\hline & Evenness (E) & 0.92 & 0.98 & 0.91 & 0.98 & 0.96 & 1.00 \\
\hline \multirow{4}{*}{71} & Number of individual (individuals/ 5 net)s & 25 & 18 & 15 & 21 & 10 & 8 \\
\hline & Diversity (H') & 2.50 & 2.26 & 2.43 & 2.33 & 1.97 & 2.08 \\
\hline & Dominance (D) & 0.16 & 0.17 & 0.13 & 0.19 & 0.30 & 0.13 \\
\hline & Evenness (E) & 0.95 & 0.94 & 0.98 & 0.94 & 0.95 & 1.00 \\
\hline \multirow{4}{*}{85} & Number of individual (individuals/ 5 nets) & 22 & 15 & 22 & 13 & 13 & 7 \\
\hline & Diversity (H') & 2.21 & 2.08 & 2.31 & 2.10 & 2.35 & 1.95 \\
\hline & Dominance (D) & 0.23 & 0.20 & 0.18 & 0.23 & 0.15 & 0.14 \\
\hline & Evenness $(\mathrm{E})$ & 0.86 & 0.95 & 0.93 & 0.95 & 0.98 & 1.00 \\
\hline \multirow{4}{*}{ Mean } & Number of individual (individuals/ 5 nets) & 16.83 & 14.17 & 14.00 & 13.17 & 10.67 & 8.01 \\
\hline & Diversity (H') & 2.51 & 2.51 & 2.59 & 2.28 & 2.35 & 2.51 \\
\hline & Dominance $(\mathrm{D})$ & 0.18 & 0.15 & 0.16 & 0.18 & 0.19 & 0.17 \\
\hline & Evenness $(\mathrm{E})$ & 0.87 & 0.87 & 0.88 & 0.82 & 0.83 & 0.93 \\
\hline
\end{tabular}

Table 10. Community characteristics of neutral insects inhabiting on the paddy applied with bioinsecticide of Beauveria bassiana,

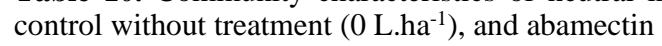

\begin{tabular}{|c|c|c|c|c|c|c|c|}
\hline \multirow{2}{*}{$\begin{array}{l}\text { Paddy age } \\
\text { (days) }\end{array}$} & \multirow{2}{*}{ Community characteristics } & \multicolumn{5}{|c|}{ Beauveria bassiana L.ha $^{-1}$} & \multirow[t]{2}{*}{ Abamectin } \\
\hline & & $\mathbf{0}$ & 1 & 2 & 3 & 4 & \\
\hline \multirow[t]{4}{*}{15} & Number of individual (individuals/ 5 nets) & 4 & 3 & 1 & 0 & 2 & 1 \\
\hline & Diversity (H') & 1.04 & 1.10 & 0.00 & 0.00 & 0.69 & 0.00 \\
\hline & Dominance (D) & 0.50 & 0.33 & 1.00 & 0.00 & 0.50 & 1.00 \\
\hline & Evenness (E) & 0.95 & 1.00 & 0.00 & 0.00 & 1.00 & 0.00 \\
\hline \multirow[t]{4}{*}{29} & Number of individual (individuals/ 5 nets) & 2 & 2 & 2 & 1 & 1 & 1 \\
\hline & Diversity (H') & 0.69 & 0.69 & 0.69 & 0.00 & 0.00 & 0.00 \\
\hline & Dominance (D) & 0.50 & 0.50 & 0.50 & 1.00 & 1.00 & 1.00 \\
\hline & Evenness (E) & 1.00 & 1.00 & 1.00 & 0.00 & 0.00 & 0.00 \\
\hline \multirow[t]{4}{*}{43} & Number of individual (individuals/ 5 nets) & 5 & 4 & 2 & 3 & 4 & 5 \\
\hline & Diversity (H') & 0.67 & 0.69 & 0.69 & 0.00 & 0.69 & 1.05 \\
\hline & Dominance (D) & 0.60 & 0.50 & 0.50 & 1.00 & 0.50 & 0.40 \\
\hline & Evenness (E) & 0.97 & 0.63 & 1.00 & 0.00 & 1.00 & 0.96 \\
\hline \multirow[t]{4}{*}{57} & Number of individual (individuals/ 5 nets) & 2 & 3 & 4 & 6 & 3 & 2 \\
\hline & Diversity (H’) & 0.00 & 0.73 & 0.69 & 1.24 & 0.64 & 0.69 \\
\hline & Dominance (D) & 1.00 & 0.33 & 0.50 & 0.50 & 0.67 & 0.50 \\
\hline & Evenness (E) & 0.00 & 0.67 & 1.00 & 0.90 & 0.92 & 1.00 \\
\hline \multirow[t]{4}{*}{71} & Number of individual (individuals/ 5 nets) & 4 & 4 & 4 & 5 & 3 & 3 \\
\hline & Diversity (H') & 1.04 & 1.04 & 0.56 & 1.05 & 0.64 & 1.10 \\
\hline & Dominance (D) & 0.50 & 0.50 & 0.75 & 0.40 & 0.67 & 0.33 \\
\hline & Evenness (E) & 0.95 & 0.95 & 0.81 & 0.96 & 0.92 & 1.00 \\
\hline \multirow[t]{4}{*}{85} & Number of individual (individuals/ 5 nets) & 5 & 3 & 5 & 5 & 4 & 5 \\
\hline & Diversity (H') & 0.67 & 0.64 & 0.95 & 1.05 & 0.69 & 0.95 \\
\hline & Dominance (D) & 0.60 & 0.67 & 0.60 & 0.40 & 0.50 & 0.60 \\
\hline & Evenness (E) & 0.97 & 0.92 & 0.86 & 0.96 & 1.00 & 0.86 \\
\hline \multirow[t]{4}{*}{ Mean } & Number of individual (individuals/ 5 nets) & 3.66 & 3.17 & 2.99 & 3.33 & 2.66 & 2.83 \\
\hline & Diversity (H') & 1.24 & 1.43 & 1.09 & 1.26 & 1.14 & 1.28 \\
\hline & Dominance (D) & 0.55 & 0.42 & 0.61 & 0.55 & 0.50 & 0.41 \\
\hline & Evenness (E) & 0.77 & 0.89 & 0.78 & 0.78 & 0.83 & 0.92 \\
\hline
\end{tabular}


The abundance of herbivores started to decrease when applied with bioinsecticides of 2, 3 or $4 \mathrm{~L}^{-h^{-1}}{ }^{-1}$, but at doses of 3 or $4{\mathrm{~L} . h a^{-1}}$ the diversity of species of non-target arthropods (predators and parasitoids) began to decrease. Consequently, the ideal dose to reduce the abundance of

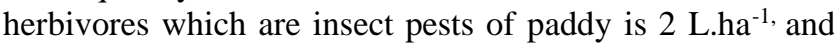
spraying is conducted when the abundance of predators and parasitoids is low. Herbivores decreased in abundance after bioinsecticides derived from $B$. bassiana were applied; and the herbivores found in this study included $N$. lugens, $P$. mathias, Spodoptera litura. Herbivores found to be attacked by $B$. bassiana in the field were $P$. mathias and $S$. litura and both belonged to the Lepidoptera Order.

The ill Lepidoptera larvae found in the bioinsecticide plot were shown to show characteristics that were attacked by $B$. bassiana. Caterpillars were found hanging on the tips of paddy leaves and their bodies were dry, hard, and stiff. The ventral abdomen was covered with white mycelia. This sick caterpillar did not smell. The fungus from the sick caterpillar after being isolated and grown on SDA media resulted in a white colony and conidia growing in a round shape and hyaline color. The fungal morphological features found were in accordance with the results of identification of $B$. bassiana by Humber (2005) stating that mycelia of $B$. bassiana arises from the exoskeleton of insects and covers all parts of the integument surface so that the insect bodies are visibly white, reverse pale to yellow colony, hyaline or colorless, 1-celled, and globular and conidia, and insulated hypha. The characteristics of $P$. mathias larvae attacked by $B$. bassiana were the same as those of insects ( $N$. lugens) attacked by $B$. bassiana which, according to Sumikarsih et al. (2019), the body is dry, hard, stiff, and odorless and from the insect's body appears white mycelia.

Although the data of the abundance of non-target arthropods (spiders, predatory arthropods, and parasitoids) did not decrease when overdosed bioinsecticide was applied, their species diversity tended to decrease when applied with bioinsecticide doses of 3 and 4 L.ha ${ }^{-1}$ or abamectin. This decrease resulted from the reduced number of species that survived in plots applied with bioinsecticide doses of 3 and 4 L.ha ${ }^{-1}$ or abamectin. Therefore, this study does not recommend using doses of 3 or $4 \mathrm{~L}$ per 2 weeks because the non-target species that have immature stages (eggs, larvae, and pupae) in the soil can reduce their species. The highest decrease in the number of species was found in the plot applied with abamectin. Some species of non-target arthropods got sensitive to abamectin applications, namely species of web-building spiders and Carabidae (Prabawati et al. 2019), parasitoids (Anagrus nilaparvatae) (Sasmito et al. 2017). In this study, the spider species sensitive to high doses of bioinsecticides ( 3 and 4 L.ha-1) were Camaricus formosus, Oxyopes matiensis, while the predatory arthropods included Ischnura senegalensis, Libellula luctuosa, Ortetrum Sabina. The spider species sensitive to abamectin were Camaricus formosus, Tetragnatha maxillosa, Oxyopes matiensis, Pardosa birmanica, Pardosa patapatensis, Pardosa pullata, while the predatory arthropods were Libellula sp., Neurothemis fluctuans, Ortetrum sabina, Ortetrum testaceum, Mantis religiosa, Conocepahalus longipenis
Neutral insects of the Diptera order decreased in abundance in the plots applied with abamectin. Although they were neutral for plants, they were important in the agro-ecosystem for alternative prey to the generalist predators (spiders). According to Settle et al. (1996), neutral insects can maintain the existence of generalist predators when in the fields under a condition without herbivores. In this study, a decrease in abundance was found in the Diptera Order by abamectin. Therefore, abamectin in addition to reducing the abundance of spiders, predatory arthropods, reduced the abundance of neutral insects and showed that the abamectin was broad-spectrum (Ananiev et al. 2002).

The results of this study conclude that bioinsecticide $B$. bassiana of doses of 3 and 4 L.ha $^{-1}$ applied every two weeks has an impact on reducing the number of non-target arthropods species (spiders, predatory arthropods, and parasitoids), but bioinsecticides $B$. bassiana has no impact to the abundance of spiders, predatory arthropods, and parasitoids. The ideal dosage to reduce the abundance of

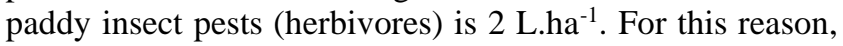
the right dose to suppress the abundance of paddy insect pests by not decreasing the abundance and diversity of nontarget species is 2 L.ha $^{-1}$. Bioinsecticide spraying should be carried out when the abundance of insect pests is high, while the abundance of predators and parasitoids is still low in the fields so that spraying does not have an impact on decreasing the abundance and diversity of non-target arthropod species.

\section{ACKNOWLEDGEMENTS}

Thank you to the sponsor of this research, the Master Thesis Research (Penelitian Tesis Magister) program, Directorate of Research and Community Service (DRPM), Directorate General of Research and Development, Ministry of Research, Technology and Higer Education, Ijdonesia, with contract number: 096/SP2H/LT/DRPM/IV/ 2019. This research was chaired by SH.

\section{REFERENCES}

Ananiev EDK, Ananieva K, Abdulova G, Christova N, Videnova E. 2002. Effects of abamectin on protein and RNA synthesis in primary leaves of Cucurbita pepo L. (Zucchini). Bulgarian J Plant Physiol 28: 85-91.

Ayudya DR, Herlinda S, Suwandi S. 2019. Insecticidal activity of culture filtrates from liquid medium of Beauveria bassiana isolates from South Sumatra (Indonesia) wetland soil against larvae of Spodoptera litura. Biodiversitas 20: 2101-2109.

Barrion A, Litsinger J. 1995. Riceland spiders of South and Southeast Asia. Entomology Division, International Rice Research Institute, Los Banos, Philippines.

Firouzbakht H, Zibaee A, Hoda H, Sohani MM. 2015. Virulence determination of Beauveria bassiana isolates on a predatory Hemipteran, Andrallus spinidens Fabricius (Hemiptera: Pentatomidae). Acta Phytopathol Entomol Hungarica 50: 115-125.

Gholamzadeh-Chitgar M, Hajizadeh J, Ghadamyari M, Karimi-Malati A, Hoda H. 2017. Effect of sublethal concentration of Beauveria bassiana fungus on demographic and some biochemical parameters of predatory bug, Andrallus spinidens Fabricius (Hemiptera: Pentatomidae) in laboratory conditions. Trakia J Sci 15: 160-167. 
Herlinda S, Yudha S, Thalib R, Khodijah, Suwandi, Lakitan B, et al. 2018. Species richness and abundance of spiders inhabiting rice in fresh swamps and tidal lowlands in South Sumatra, Indonesia. J ISSAAS 24: 82-93.

Herlinda S, Yusticia SR, Irsan C, Asmara B, Hadi R. 2019a. Abundance of arthropods inhabiting canopy of rice cultivated using different planting methods and varieties. J Biopest 12: 7-18.

Herlinda S, Karenina T, Irsan C, Pujiastuti Y. 2019b. Arthropods inhabiting flowering non-crop plants and adaptive vegetables planted around paddy fields of freshwater swamps of South Sumatra, Indonesia. Biodiversitas 20: 3328-3339.

Humber RA. 2005. Entomopathogenic Fungal Identification. USDA-ARS Plant Protection Research Unit: Ithaca.

Kalshoven LG. 1981. The Pest of Crops in Indonesia. Van Hoeve, Jakarta : P. T. Ichtiar Baru.

Karenina T, Herlinda S, Irsan C, Pujiastuti Y. 2019. Abundance and species diversity of predatory arthropods inhabiting rice of refuge habitats and synthetic insecticide application in freshwater swamps in South Sumatra, Indonesia. Biodiversitas 20: 2375-2387.

Lakitan B, Lindiana L, Widuri LI, Kartika K, Siaga E, Meihana M. 2019. Inclusive and ecologically-sound food crop cultivation at tropical non-tidal. Agrivita 41: 23-31.

Li M, Li S, Xu A, Lin H, Chen D, Wang H. 2014. Selection of Beauveria isolates pathogenic to adults of Nilaparvata lugens. J Insect Sci 14: 112.

Magurran AE. 1988. Ecological Diversity and its Measurement. Chapman and Hall, London.

McAlpine JF, Peterson BV, Shewell GE, Teskey HJ, Vockeroth JR, Wood DM. 1987. Manual of Neartic Diptera. Agriculture Canada, Research Branch.

Ngin C, Suon S, Tanaka T, Yamauchi A, Kawakita K, Chiba S. 2017. Impact of insecticide applications on arthropod predators and plant feeders in Cambodian rice fields. Phytobiomes J 1: 128-137.
Prabawati G, Herlinda S, Pujiastuti Y. 2019. The abundance of canopy arthropods in South Sumatra (Indonesia) freshwater swamp main and ratooned rice applied with bioinsecticides and synthetic insecticide. Biodiversitas 20: 2921-2930.

Safitri A, Herlinda S, Setiawan A. 2018. Entomopathogenic fungi of soils of freshwater swamps, tidal lowlands, peatlands, and highlands of South Sumatra, Indonesia. Biodiversitas 19: 2365-2373.

Sasmito EK, Trisyono YA, Harjaka T. 2017. Impact of abamectin on Anagrus nilaparvatae, an egg parasitoid of Nilaparvata lugens. Jurnal Perlindungan Tanaman Indonesia 21: 80-86. [Indonesian]

Settle WH, Ariawan H, Astuti ET, Cahyana W, Hakim AL, Hindayana DH, Lestari AS. 1996. Managing tropical rice pests through conservation of generalist natural enemies and alternative prey. Ecology 77: 1975-1988.

Siaga E, Lakitan B, Hasbi H, Bernas SM, Widuri LI, Kartika K. 2019. Floating seedbed for preparing rice seedlings under unpredictable flooding occurrence at tropical riparian wetland. Bulgarian J Agric Sci 25: 326-336.

Sumikarsih E, Herlinda S, Pujiastuti Y. 2019. Conidial density and viability of Beauveria bassiana isolate from Java and Sumatra and their virulence against Nilaparvata lugens at different temperatures. Agrivita 41: 335-349.

Suwandi, Ammar M, Irsan C. 2012. Aplikasi ekstrak kompos meningkatkan hasil dan menekan penyakit padi sistem ratun di sawah pasang surut Kabupaten Banyuasin. Jurnal Lahan Suboptimal 1: 116122. [Indonesian]

Weilhoefer CL, Williams D, Nguyen I, Jakstis K, Fischer C. 2017. The effects of reed canary grass (Phalaris arundinacea L.) on wetland habitat and arthropod community composition in an urban freshwater wetland. Wetlands Ecol Manag 25: 159-175.

Yuliani D. 2016. Metarhizium anisopliae and Andrographis paniculata to Non-Target Insect Pests. Jurnal Ilmu Pertanian Indonesia 21: 20-25. [Indonesian] 